remains to be seen. For the past eighteen months the Ministry of Power has been working on a model of Britain's fuel economy, and within six weeks hopes to have the five sub-models-one for consumer demand and one for supply from each of the four fuel industries -which will give a picture of the fuel situation in Britain over the next 20 years, for any given set of conditions.

The impetus for the model came in 1966 after the discovery of natural gas in the North Sea, when Mr Richard Marsh, then Minister of Power, called for a wide-ranging review of fuel policy. This led to a statistical analysis of various possible long-term demands for fuel in different circumstances-variations of oil taxes or developments in nuclear power, for example. The four industries-gas, oil, coal and nuclear power-were asked to estimate how each would be affected, what decisions would be made regarding such factors as investment and manpower and what their prices would be. These analyses gave interesting results but each set of results took four to six months to work out and had to neglect far too many factors. The new model is an attempt to formalize the sequence so that, for each given set of assumptions, the computer can turn out an estimate of the final demand in hours rather than months.

For each set of conditions, the consumer demand for energy from one sub-model will be fed into the other sub-models for each fuel industry which, given the wage rates and other industrial costs, will give the total industrial cost to meet that demand. With demand and cost determined, the final price for fuel will emerge and can be fed back into the model to see how it will affect the initial assumption about consumer demand; one would hope that the solutions would eventually converge into a steady state condition for each particular case. The model, by the very nature of the fuel situation, must be representational rather than optimizing, for there are too many social factors involved that cannot be quantified.

\section{Eat More Leaves}

THere are now some hopeful signs that a machine for extracting edible protein from leaves, developed by $\mathrm{Mr}$ N. W. Pirie at Rothamsted Experimental Station as long ago as 1953, may at last start work in two underdeveloped countries. A British charity called "Find your Feet", with the moral support of the World Health Organization and the Food and Agriculture Organization, launched a campaign last week to raise funds to send one machine to East Africa, probably to Uganda, and another to India. Three machines have already been sent from Rothamsted to India and one each to Nigeria, New Guinea and Ireland, but all six have so far been used solely for experimental work at research stations. The sponsors claim, however, that evidence from feeding trials in Madras, available only in the past two months, has proved that the material is an acceptable and effective protein supplement for children. This could tip the scales in favour of the machine, for practical experience has so far impeded its introduction.

The remarkable simplicity and cheapness of the machine-it costs about $£ 8,000$ and annual running costs are about $f 10,000$-are two important selling points in underdeveloped countries. By siting machines in villages, elaborate storage facilities and distribution networks can be dispensed with. In the operation of the machine, leaves of a crop are mixed with water and fed first into a pulper and then into a press which separates the protein solution from the fibrous material. The protein solution is then mixed with steam and the denatured protein floats to the surface as a green scum which can be filtered off, washed and dried. The recovery of protein ranges from 50-75 per cent, and even the 25 per cent remaining in the fibrous

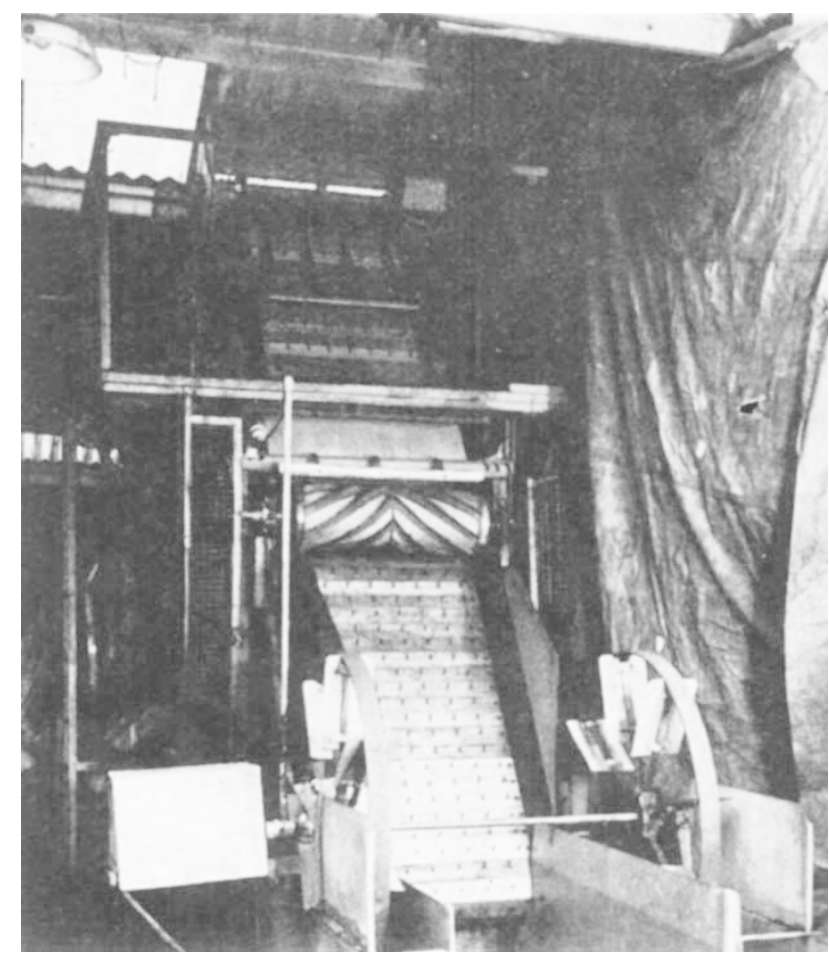

The leaf lift at the start of the process.

residue can be used for animal feeds. The machine has a maximum capacity of one ton per hour and, at Rothamsted, 40 pounds of pure dry protein can be extracted from a ton of clover, wheat or mustard leaves.

According to Mr Pirie, the green protein extract has a mildly grassy flavour which can easily be masked. It is intended only to be a protein supplement and not a complete diet, and has about the same nutritional value as fish meal or meat, but less than milk or eggs. It has more of the essential amino-acids than the pro. tein from cereals or other seeds and, given a continuous supply of leaves, a single machine should produce enough high class protein to provide 40,000 to 60,000 people with one-tenth of their daily requirement.

The machine is, of course, of little use in semi-arid regions, but it is ideally suited to humid tropical regions with no winter. Weed plants and tree leaves can be processed, but the problems of harvesting rule them out as practical and continuous sources of raw material. The problem to be solved is therefore that of deciding on a suitable crop sequence to provide a continuous supply of leaves throughout the year. Potatoes, cassava, jute, peas, beans, wheat, beet and sweet potatoes have all been used successfully in trials, and it is claimed that the yield of protein per hectare 
can be at least doubled if crops are harrested when the foliage is at its most lush, not simply when the crop is ready for conventional harvesting. A side benefit is that the land is by this means set free more quickly for resowing. At Rothamsted during 1967-68, an acre produced 1,400 pounds of extracted protein, and in Mysore, where growth continues through the winter, an acre yielded 1.2 tons of the protein.

\section{All Fall Down}

THE National Tower Testing Station is one of the most unusual laboratories in Britain. It is sited in a deep quarry in Somerset, just around the corner from the Cheddar Gorge. Although the station was built by the Central Electricity Generating Board, it will undertake tests of struetures for anybody prepared to pay the quite modest charges. The station offers the opportunity for full scale testing of structures such as electricity transmission towers, which cannot be tested effectively at model scale. Even a small improvement on a tower of which 5,000 examples are to be built can be important, specially if it makes it possible for the tower to be made lighter, with the saving of a ton or so of steel.

The structures to be tested are assembled on the floor of the quarry and firmly anchored to the rock through anchor points. Stresses are applied to the

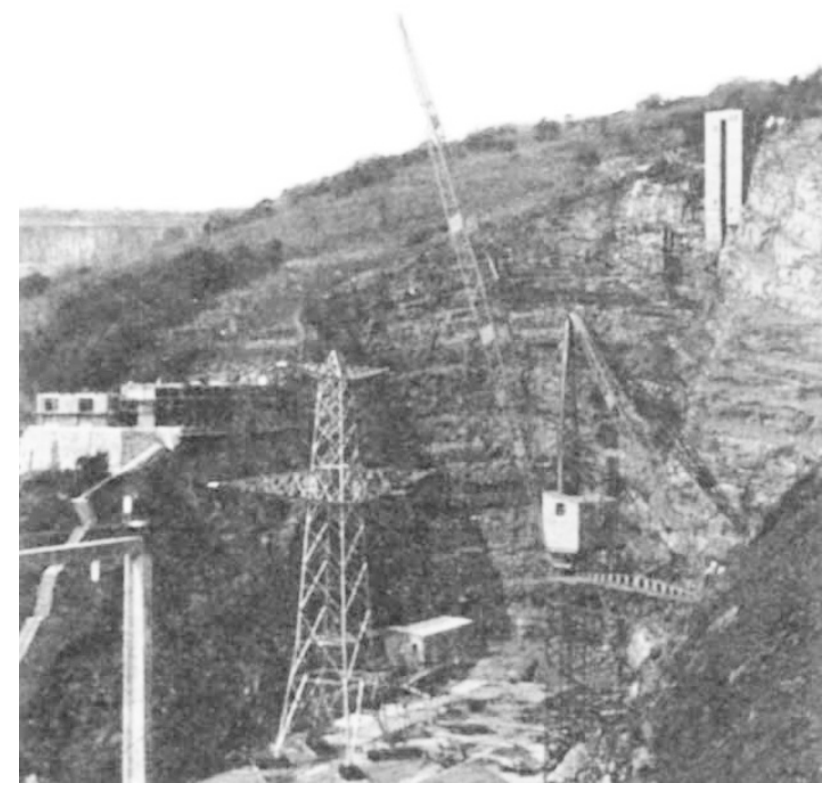

towers through steel wires attached to two rams in the side of the quarry-one can be seen in the pictureand hydraulic rams anchored to the floor. A variety of different tests can be carried out, leading ultimately to a test to destruction which reveals whether or not the structure fulfils specification. The picture shows a new type of $400 \mathrm{kV}$ tower being tested for the CEGB which is only 100 feet high, compared with the 165 feet of the usual $400 \mathrm{kV}$ tower.

Last week, the station tested to destruction a 200 foot tower built for the Atomic Energy Commission of Canada. But it is also capable of testing much smaller structures, such as glass-fibre components or yacht masts. The station is about to begin work on wooden telegraph poles, which have never been systematically tested before. In effect, the station is being used to calibrate the inspectors, who usually decide when a pole shall be condemned on visual appearance alone. The station would also like the chance to test the steel frame structures used for large buildings. A structure up to 13 storeys high could be tested, and, for an expenditure of $\mathfrak{£} 10,000$ to $£ 12,000$, enormously valuable information could be gained. No building structures as large as this have ever been tested in Britain, though they are widely used.

\section{Another Look at CERN}

THe House of Commons Select Committee on Science and Technology has decided to investigate the British Government's decision not to support the CERN $300 \mathrm{GeV}$ machine. The committee, which announced this in a special report last week, will also be investiga. ting fusion research at Culham Laboratory and the development of carbon fibre materials.

These will not be full-blooded investigations on the lines of the present investigation into defence research. Instead, they will be carried out by the General Purposes Sub-Committee of the full committee. The subcommittee has six members - Mr Arthur Palmer (chairman of both the select committee and the sub-committee), Mr Tam Dalyell, Dr Edmund Davies, Mr Eric Iubbock, Mr David Price and Mr Airey Neave. The sub-committee has not yet started work, and nothing very serious is likely to happen until after the recess. $\mathrm{Mr}$ Palmer says that, because of the importance of the investigation into defence research, the committee thought there was a danger of other matters being overlooked. It had therefore decided to set up machinery to make rapid assessments of important issues without going into the elaboration of a full report. On the CERN decision, he points out that "the minister made no statement to the House, and there is no chance of a full debate". In these circumstances, the committee thought it important that it should make an investigation. The immediate intention is to bring all the available documents together and to consider them. If further information is needed, witnesses can, of course, be called. Mr Edward Short, the minister responsible for the decision, is an obvious candidate.

The investigation into Culham follows the last major investigation into the British nuclear power programme. In that report, the committee said that it would be taking a continuing look at fusion research. As for carbon fibres, it seems that the committee was concerned by reports in the press that British firms are not developing carbon fibre technology sufficiently vigorously. Rolls-Royce, one of the companies involved, has denied this. The suggestion has also been made that the Ministry of Technology, dissatisfied by the rate of development, is considering handing the whole problem over to the Harwell Laboratory of the AEA. If there is any truth in these reports, the committee will do well to investigate them. But RollsRoyce, which has already won a major contract on the strength of the new technology, must be feeling understandably bitter that its enthusiasm has already been callod into question.

The other sub-committee of the Select Committee, which has been investigating coastal pollution, has now 